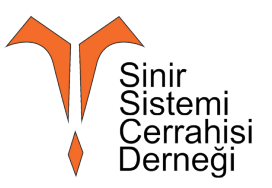

\section{Programmable shunt valve affected by behind-the-ear hearing device: A case report and literature review}

\author{
Kulak arkası işitme cihazından etkilenen \\ ayarlanabilir şant valfi: Olgu sunumu ve \\ literatür taraması
}

\author{
Furkan Diren $^{1 \oplus}$, Osman Boyalı ${ }^{1 \oplus}$, Eyüp Can Savrunlu ${ }^{1 \oplus}$, Erdinç Civelek ${ }^{1 \oplus,}$ \\ Serdar Kabataş ${ }^{1 \oplus}$
}

${ }^{1}$ Sağlık Bilimleri Üniversitesi, Gaziosmanpaşa Eğitim ve Araştırma Hastanesi, Beyin ve Sinir Cerrahisi Kliniği, İstanbul.

Atıf/Cite as: Diren F, Boyalı O, Savrunlu EC, Civelek E, Kabataş S. Programmable shunt valve affected by behind-the-ear hearing device: A case report and literature review. J Nervous Sys Surgery 2021;7(3):106-111.

Geliş tarihi/Received: 26.11.2021 Kabul tarihi/Accepted: 27.12.2021 Yayın tarihi/Publication date: 10.01.2022

\begin{abstract}
Background: It is known that interactions between programmable Ventriculoperitoneal Shunt (VPS) valves and electromagnetic and hearing devices may change the valve settings. We reported a patient using programmable VPS valves and hearing devices and reviewed the literature.

Case Description: A 71-year-old man was implanted with a programmable VPS valve with the diagnosis of Normal Pressure Hydrocephalus. A hearing device (behind-the-ear) was proposed because of hearing difficulties, but it was suggested that it be discontinued because it did not help. However, the patient used it twice because of his current dementia, forgetting the doctor's recommendations. The setting of the valve has changed in these two different times that this behind-the-ear hearing device is used. Long-term follow-ups showed no change in valve settings except those two situations.

Conclusion: It is important to note that patients using hearing devices and programmable VPS valves are a unique group of patients. There are not enough studies showing the relationship between the behind-the-ear hearing devices and programmable VPS. It should be kept in mind that hearing devices with magnetic field strength may change the setting of the valves.
\end{abstract}

Keywords: Hydrocephalus, Hear devices, Programmable shunt valve

ÖZ

Amaç: Ayarlanabilir Ventriküloperitoneal Şant (VPŞ) valfleri ile elektromanyetik aletler ve işitme cihazları arasındaki etkileşimlerin valf ayarlarını değiştirebileceği bilinmektedir. Ayarlanabilir VPŞ valfleri ve işitme cihazları kullanan bir hastayı rapor ettik ve literatürü gözden geçirdik.

Olgu Sunumu: 71 yaşında erkek hasta, Normal Basınçlı Hidrosefali tanısı ile ayarlanabilir bir VPŞ valfi

Sorumlu yazar/Corresponding author: Furkan Diren, Sağlık Bilimleri Üniversitesi, Gaziosmanpaşa Eğitim ve Araştırma Hastanesi, Beyin ve Sinir Cerrahisi Kliniği, İstanbul. furkandiren@yahoo.com / 0000-0001-6169-9722

ORCID:

O. Boyalı 0000-0002-2500-1718, E. C. Savrunlu 0000-0001-9022-200X, E. Civelek 0000-0002-3988-4064,

S. Kabataş 0000-0003-2691-6861

(c) Telif hakkı Sinir Sistemi Cerrahisi Dergisi.

Bu dergide yayınlanan bütün makaleler Creative Commons 4.0 Uluslararası Lisansı (CC-BY) ile lisanslanmıştır.

(c) Copyright Journal of Nervous System Surgery.

Licenced by Creative Commons Attribution 4.0 International (CC BY). 
yerleştirildi. İşitme güçlüğü nedeniyle daha önceden işitme cihazı (kulak arkası tip) kullanıyordu, ancak yardımcı olmadığı için kullanmaması önerildi. Bununla birlikte, hasta mevcut demansı nedeniyle doktor tavsiyelerini unutarak iki kez kullandı. Kulak arkası işitme cihazını kullandığı iki farklı zamanda da valfin ayarı değişti. Uzun süreli takiplerde bu iki durum dışında valf ayarlarında bir değişiklik görülmedi.

Sonuç: İşitme cihazları ve ayarlanabilir VPŞ valfleri kullanan hastaların öenmli bir hasta grubu olduğuna dikkat etmek gerekir. Kulak arkası tip işitme cihazı ve ayarlanabilir VPŞ arasındaki ilişkiyi gösteren yeterli çalışma yoktur. Manyetik alan gücüne sahip işitme cihazlarının valfin ayarını değiştirebileceği unutulmamalıdır.

Anahtar Kelimeler: Kulak arkası tip İşitme Cihazı, ayarlanabilir şant valfi, etkileşim

\section{INTRODUCTION}

Normal-pressure hydrocephalus (NPH) is a chronic disorder in which patients present with impaired gait, urinary disturbances, and complaints of mild cognitive impairment (1). It is a differential diagnosis for most of the dementia syndromes and occurs mainly in elderly populations ${ }^{(2)}$. The known incidence is approximately 5.5 per 100.000 and it has a prevalence of 22 per 100.000 for suspected NPH (2). Ventriculoperitoneal shunt (VPS) systems are used in the treatment of this illness. Programmable VPS valves allow for adjustable control of cerebrospinal fluid (CSF) flow using an external magnetic field. The orientation of valve mechanisms can generally be changed by a rotation that coordinates with the direction that the magnet is turned, modifying the opening pressure or rate of flow through the valve ${ }^{(3)}$. The ease of adjustment of these valves via a magnetic eld comes with the downside of erroneous valve adjustment when exposed to other magnetic fields. This has been investigated in the setting of magnetic toys, magnetic tablet covers, cell phones, televisions, amusement park rides, and headphones (4).

Hearing loss is an elderly population disease such as NPH. Approximately $30 \%$ of individuals aged 65 and older have some degree of hearing loss, with estimates ranging from $70 \%$ to $90 \%$ of those aged 85 and older ${ }^{(5)}$. Historically, hearing devices (HD) have been the primary remediation option for individuals affected by medically uncomplicated presbycusis (age-related hearing loss) ${ }^{(6)}$. HD technology has been available for more than a century, and in the last few decades, the variety and quality of hearing devices have increased ${ }^{(6)}$. The functional rehabilitation of deafness is based on the use of hearing devices by aerial or bone conduction or of auditory implants. There are three types of auditory implants available: boneanchored hearing implants, middle ear implants, and cochlear implants (CI) ${ }^{(7)}$.

Patients with hearing loss and a VPS represent an important population. Data on the interaction between HD and programmable VPS valves are limited.

We present the case of a 71 years old man who used a hearing device and his hearing device changed in valve setting one week after programmable VPS surgery.

\section{CASE DESCRIPTION}

A 71-years old male patient, with a history of a right-side hearing loss and coronary stenting, presented with progressive gait disturbances, dementia, and urinary incontinence. Clinical examination and imaging findings suggested a NPH.

It was learned that the patient used the HD irregularly. The patient was consulted to the otorhinolaryngology department because both the HD and the place where the valve was planned to be placed were on the right side. The examinations revealed that the HD did not treat hearing loss and that the patient did not need to use it anymore. 
We placed a VPS (Medtronic Strata II ${ }^{\mathrm{TM}}$ programmable valve) with the valve set at setting 1.5 from the right Kocher point. The programmable VPS valve is positioned behind the ear. The postoperative course was uneventful and a significant improvement of the gait and urinary incontinence were observed. He was discharged on the fourth day after being warned not to use a behind-the-ear (BTE) hearing device (Oticon GET BTE standard). Follow-up at the outpatient clinic after one week confirmed a further improvement of the gait and his urinary symptoms with a normal computer tomography scan at that time. However, the patient wore it the day before, forgetting that he should not use the BTE hearing device. VPS valve setting was checked and it was found setting 0.5 , upon this valve set at setting 1.5 again. The patient was called to weekly outpatient visits and we checked the valve setting regularly. The VPS valve setting has not changed. At the fourth visit, it was learned that he had forgotten to use the HD again and the valve setting was found setting 0.5 . The valve was again set to 1.5. The valve setting did not change again at the weekly polyclinic control for three months.

Written informed consent was obtained from the patient for publication of this case report and any accompanying images.

\section{DISCUSSION}

Nowadays, it is thought that many electronic devices that are used extensively in life can affect and change the programmable VPS valves. Headphones, cell phones, magnetic toys, park rides, television, and tablet computers are a few of them. Spader investigated interactions with three different headphones and three different programmable VPS valves and found that it generated a magnetic field less than $5 \mathrm{~mm}$ away. The programmable valve settings only changed at a distance of $0 \mathrm{~mm}$. They thought that the programmable valve placed under the skin would not be affected ${ }^{(8)}$. It is predicted that cell phones and the electromagnetic waves it emits can change the setting of the programmable VPS valves. In the study conducted with Strata, Codman and Sophy valves, it was found that cell phones could theoretically affect the valves and Strata was more sensitive than the others ${ }^{(9)}$. In a study measuring the magnetic relationship between the tablet computer and the programmable VPS valve, it was found that the valve setting changed $58 \%$ at a distance of less than $1 \mathrm{~cm}$ and that the valve was not affected at distances greater than 5 $\mathrm{cm}{ }^{(10)}$. In the study, which calculated the effect of Magnetic toys on Strata II small (Medtronic Inc.), Codman Judge (Codman \& Shurtleff), and Polaris (Sophysa) programmable VPS valves; it has been reported that the Polaris valve setting did not change in any way, the adjustment of the Codman valve up to $30 \mathrm{~mm}$ and the Strata valve up to $50 \mathrm{~mm}$ are affected ${ }^{(10)}$. There are also publications suggesting that park rides and television can change the setting of programmable VPS valves ${ }^{(11)}$.

Strong magnetic fields can potentially alter the pressure setting of programmable shunt valves. Various HDs are also a major problem because of the strong magnetic field strength. This is because HDs and programmable VPS valves are used together in both pediatric and elderly populations. To date, most of the study on this topic is related to cochlear implantation and programmable VPS valve. In these studies, the $\mathrm{CI}$ and programmable valve that creates a significant problem in the use of VPS and magnetic field strength can change the valve settings are highlighted. However, it is known that the magnetic field strength decreases inversely proportional to the square of the distance. It has been noted that positioning the CI as far away as possible will not affect the valve setting ${ }^{(4,12)}$. 
In the literature, there are insufficient studies to point out the relationship between behind-the-ear type HD and programmable VPS valves used by our patient. It is usually a topic covered in the title of "Hearing Device". However, technically the closest hearing device type is BTE. The BTE and the programmable VPS valve are located almost overlapping behind the ear. A BTE HD consists of a sound receiving microphone, a loudspeaker, an amplifier, and a battery. The magnetic field strength provided by these parts may have changed the valve setting. The patient's valve setting changed twice after using BTE HD and the valve setting did not change in other controls, suggesting that it was the magnetic field strength of BTE HD. Oticon BTE HD instructions for use are warned to keep it $30 \mathrm{~cm}$ away from magnetically sensitive devices. In the warnings and precautions section of the Strata valve instructions for use, "devices with known magnet content should be kept away from the valve as this may change the performance level of the valve".

In this case, we believe that the setting of the programmable VPS valve is changed by BTE HD. The patient using his discontinued HD due to forgetfulness caused the valve to change the setting. Patients with a history of using or hearing devices should be more careful when using the programmable VPS valve, the patient's family, surgeons, and paramedics. In particular, neurosurgeons may consider positioning shunt surgery behind the contralateral ear where the valve is used. Nowadays, it is thought that many electronic devices that are used extensively in life can affect and change the programmable VPS valves. Headphones, cell phones, magnetic toys, park rides, television, and tablet computers are a few of them. Spader investigated interactions with three different headphones and three different programmable VPS valves and found that it generated a magnetic field less than $5 \mathrm{~mm}$ away. The programmable valve settings only changed at a distance of $0 \mathrm{~mm}$. They thought that the programmable valve placed under the skin would not be affected ${ }^{(8)}$. It is predicted that cell phones and the electromagnetic waves it emits can change the setting of the programmable VPS valves. In the study conducted with Strata, Codman and Sophy valves, it was found that cell phones could theoretically affect the valves and Strata was more sensitive than the others ${ }^{(9)}$. In a study measuring the magnetic relationship between the tablet computer and the programmable VPS valve, it was found that the valve setting changed $58 \%$ at a distance of less than $1 \mathrm{~cm}$ and that the valve was not affected at distances greater than $5 \mathrm{~cm}{ }^{(10)}$. In the study, which calculated the effect of Magnetic toys on Strata II small (Medtronic Inc.), Codman Judge (Codman \& Shurtleff), and Polaris (Sophysa) programmable VPS valves; it has been reported that the Polaris valve setting did not change in any way, the adjustment of the Codman valve up to 30 $\mathrm{mm}$ and the Strata valve up to $50 \mathrm{~mm}$ are affected (10). There are also publications suggesting that park rides and television can change the setting of programmable VPS valves ${ }^{(11)}$.

Strong magnetic fields can potentially alter the pressure setting of programmable shunt valves. Various HDs are also a major problem because of the strong magnetic field strength. This is because HDs and programmable VPS valves are used together in both pediatric and elderly populations. To date, most of the study on this topic is related to cochlear implantation and programmable VPS valve. In these studies, the CI and programmable valve that creates a significant problem in the use of VPS and magnetic field strength can change the valve settings are highlighted. However, it is 
known that the magnetic field strength decreases inversely proportional to the square of the distance. It has been noted that positioning the CI as far away as possible will not affect the valve setting ${ }^{(4,12)}$.

In the literature, there are insufficient studies to point out the relationship between behind-the-ear type HD and programmable VPS valves used by our patient. It is usually a topic covered in the title of "Hearing Device". However, technically the closest hearing device type is BTE. The BTE and the programmable VPS valve are located almost overlapping behind the ear. A BTE HD consists of a sound receiving microphone, a loudspeaker, an amplifier, and a battery. The magnetic field strength provided by these parts may have changed the valve setting. The patient's valve setting changed twice after using BTE HD and the valve setting did not change in other controls, suggesting that it was the magnetic field strength of BTE HD. Oticon BTE HD instructions for use are warned to keep it $30 \mathrm{~cm}$ away from magnetically sensitive devices. In the warnings and precautions section of the Strata valve instructions for use, "devices with known magnet content should be kept away from the valve as this may change the performance level of the valve".

In this case, we believe that the setting of the programmable VPS valve is changed by BTE HD. The patient using his discontinued HD due to forgetfulness caused the valve to change the setting. Patients with a history of using or hearing devices should be more careful when using the programmable VPS valve, the patient's family, surgeons, and paramedics. In particular, neurosurgeons may consider positioning shunt surgery behind the contralateral ear where the valve is used ${ }^{(13)}$.

\section{CONCLUSION}

The use of a hearing device and a programmable VPS valve together cause significant problems. In order to reduce these problems, pre-operative physicians and post-operative patients' families and paramedics have some assignments.

Çıkar çatışması: Çalışmamızda herhangi bir çıkar çatışması bulunmamaktadır.

Finansal destek: Çalışmamızda finansal destek alınmamıştır.

Conflict of interest: There is no conflict of interest in our study.

Funding: No financial support was received in our study.

\section{REFERENCES}

1. Adams R, Fisher C, Hakim S, Ojemann R, Sweet W: Symptomatic occult hydrocephalus with normal cerebrospinal-fluid pressure: a treatable syndrome. New England Journal of Medicine 273:117-126, 1965. https://doi.org/10.1056/NEJM196507152730301

2. Nakayama T, Ouchi Y, Yoshikawa E, Sugihara G, Torizuka T, Tanaka K: Striatal D2 receptor availability after shunting in idiopathic normal pressure hydrocephalus. Journal of Nuclear Medicine 48:1981-1986, 2007. https://doi.org/10.2967/jnumed.107.045310

3. Anderson RC, Walker ML, Viner JM, Kestle JR: Adjustment and malfunction of a programmable valve after exposure to toy magnets: case report. Journal of Neurosurgery: Pediatrics 101:222-225, 2004. https://doi.org/10.3171/ped.2004.101.2.0222

4. Pierson MJ, Wehrmann D, Albers JA, El Tecle NE, Costa D, Elbabaa SK: Programmable shunt valve interactions with osseointegrated hearing devices. Journal of Neurosurgery: Pediatrics 19:384-390, 2017. https://doi.org/10.3171/2016.11.PEDS16501

5. Chien W, Lin FR: Prevalence of hearing aid use among older adults in the United States. Archives of internal medicine 172:292-293, 2012. https://doi.org/10.1001/archinternmed.2011.1408

6. Manchaiah V, Taylor B, Dockens AL, Tran NR, Lane K, Castle M, Grover V: Applications of direct-toconsumer hearing devices for adults with hearing loss: a review. Clinical interventions in aging 12:859, 2017. https://doi.org/10.2147/CIA.S135390 
F. Diren et al. Programmable shunt valve affected by behind-the-ear hearing device: A case report and literature review

7. Nevoux J, Coez A, Truy É: Les dispositifs médicaux correcteurs de la surdité: prothèses et implants auditifs. La Presse Médicale 46:1043-1054, 2017. https://doi.org/10.1016/j.lpm.2017.09.008

8. Spader HS, Ratanaprasatporn L, Morrison JF, Grossberg JA, Cosgrove GR: Programmable shunts and headphones: Are they safe together? Journal of Neurosurgery: Pediatrics 16:402-405, 2015. https://doi.org/10.3171/2015.1.PEDS14400

9. Nomura S, Fujisawa H, Suzuki M: Effect of cell phone magnetic fields on adjustable cerebrospinal fluid shunt valves. Surgical neurology 63:467-468, 2005. https://doi.org/10.1016/j.surneu.2004.06.022

10.Strahle J, Selzer BJ, Muraszko KM, Garton HJ, Maher CO: Programmable shunt valve affected by exposure to a tablet computer. Journal of Neurosurgery: Pediatrics 10:118120, 2012. https://doi.org/10.3171/2012.3.PEDS1211
11. Strahle J, Collins K, Stetler Jr WR, Smith BW, Garton T, Garton C, Garton HJ, Maher CO: Effect of amusement park rides on programmable shunt valve settings. Pediatric neurosurgery 49:21-23, 2013. https://doi.org/10.1159/000355247

12.An Y-H, Song SJ, Yoon SW, Kim JH, Shim HJ: Cochlear implantation for total deafness after ipsilateral ventriculoperitoneal shunt surgery: technical report. Acta neurochirurgica 153:2479-2483, 2011. https://doi.org/10.1007/s00701-011-1180-5

13.Kiraz, M., Cevik, S., Demirel, A., Gergin, Y.E. and Ozdemir, O., 2018. Nanoteknoloji ve nanonöroşirürji. Türk Nöroşirürji Derg 28(3):264-272. 